\title{
Assessing the Impact of Land Use on Water Quality across Multiple Spatial Scales in U-tapao River Basin, Thailand
}

\author{
S. Gyawali' ${ }^{1}$ K. Techato ${ }^{2}$ and S. Monprapusson ${ }^{3}$ \\ ${ }^{1}$ Research and Development Centre, Nepal (RDC, Nepal), Kathmandu, Nepal \\ ${ }^{2}$ Faculty of Environmental Management, Prince of Songkla University, Hatyai, Thailand \\ ${ }^{3}$ Faculty of Social Science, Srinakharinwirot University, Bangkok, Thailand \\ Email:sbgyawali@gmail.com
}

\begin{abstract}
The study investigated the linkages between land uses and water quality in U-tapao river basin, Thailand, in order to examine the impact of land use changes on full -basin, sub-watershed and buffer zone scales $(1000 \mathrm{~m}, 500 \mathrm{~m}$ and $200 \mathrm{~m}$ ) on river water quality through Geographical Information Systems (GIS) and statistical analyses. Correlation and regression analysis were applied for ten water quality parameters. In scale analysis, in themost cases, the sub-watershed scale showed the clear relationship between land use water quality rather than full-basin and buffer zone scales. This indicates that the level of relationship between land use and water quality depends upon scale therefore the relationship between water quality parameters and land uses should be studied in multiple scales and it helps to develop effective river basin management in future.
\end{abstract}

Keywords: Land use, Multiple spatial scales, U-tapao river basin, Water quality

\section{INTRODUCTION}

Over last decade, land uses in the U-tapao river basin have been changing sharply, causing decline of agricultural area and a significant increase of urban land (Gyawali et al. 2012). Such changes modify the surface characteristics of basin and can have considerable influence on runoff quality and quantity, and may be responsible for the increase of various pollutants (Tu \& Xia 2006, Tong \& Chen 2002, Ngoye \& Machiwa 2004). Generally, surface water quality of river is contaminated by either point sources or non-point sources pollution. Mostly, point sources pollution can be easily monitored at a single place, but, non-point sources are difficult to identify since they generally cover large areas and it is believed that the changing land use pattern is one of the causes of increasing non-point sources pollution (Sliva \& Williams 2001, Zampella et al. 2007, Ojutiku \& Kolo 2011).

In past decades, many researchers did research on linking water quality with land use practices on basin or watershed levels (Tong \& Chen 2002, Ngoye \& Machiwa 2004, Sliva \& Williams 2001, Li et al. 2009, Basnyat et al. 1999, Ahearn et al. 2005). Tong and Chen (2002) found that increment in agricultural land had a strong positive correlation with conductivity and $\mathrm{pH}$ but a negative correlation with heavy metals, while increment in residential land had a positive correlation with heavy metals, biological oxygen demand, and conductivity in the watersheds of Ohio State, USA. Simi- larly, Li et al. (2009) demonstrated that temperature had negative correlation with vegetation and bare land, $\mathrm{pH}$ had negative correlation with urban land and nitrite had positive correlation with bare land in Han River Basin, China . Ahearn et al. (2005) demonstrated that nitrite and total suspended solid had positive correlation with agriculture, urban and grass land and negative correlation with forest land in Sierra Nevada, California.

On explaining the relationship of land use and water quality parameters, the geographical or spatial scale plays a vital role. Many previous studies have adjusted the scale factor on linking land use variables with water quality parameters (Tu \& Xia 2006, Tong \& Chen 2002, Ngoye \& Machiwa 2004, Sliva \& Williams 2001, Basnyat et al. 1999, Azyana \& NikNorulaini 2012, Jarvie et al. 2002, Huang et al. 2011). And, the analysis of scale is important because it determines what area researchers use to link land use/cover with a stream site's chemical and physical properties (Pratt et al. 2012). But, there is still an ongoing dispute regarding whether the land use of the entire watershed or that of the buffer zone is more important in influencing the water quality, all other factors remaining constant (Sliva \& Williams 2001). Some researchers advocated that the entire catchment explains better relationship of land use and water quality rather than buffer zone approach (Sliva \& Williams 2001, Azyana \& NikNorulaini 2012). In contrast, some researcher mentioned that the buffer zone approach gives 
the better explanation of the relationship of land use and water than entire catchment scale (Hunsaker \& Levine 1995, Johnson et al.1997).

Since many researchers have linked the land use and water quality on different scales, we know of none that have been conducted in U-tapao river basin. So, the objectives of this study were to determine the effects of land use activities on water quality and compare the influences of land use on water quality on different spatial scales. In this study, three types of scales were used: i) full-basin: the whole basin and mean water quality parameters of different locations (Fig. 1) ii) sub-watershed scale: the whole upstream drainage area of each water quality monitoring site (Fig. 2); and iii) buffer zone scales (1000m, $500 \mathrm{~m}$ and $200 \mathrm{~m}$ ): circular radii with corresponding monitoring station (Fig. 3). So, this is the first type of study on comparing land use on these spatial scales and definitely it gives a clear idea of the impact of land use on water quality parameters as well as to select appropriate scale to link the land with water quality.

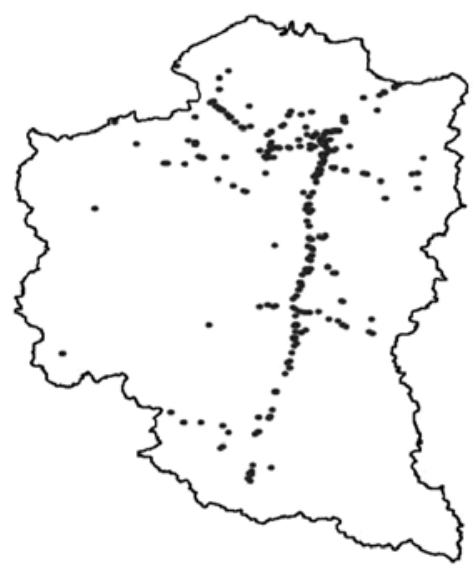

Fig. 1. Land use and water quality monitoring stations of $\mathrm{U}$-tapao river basin in full-basin scale

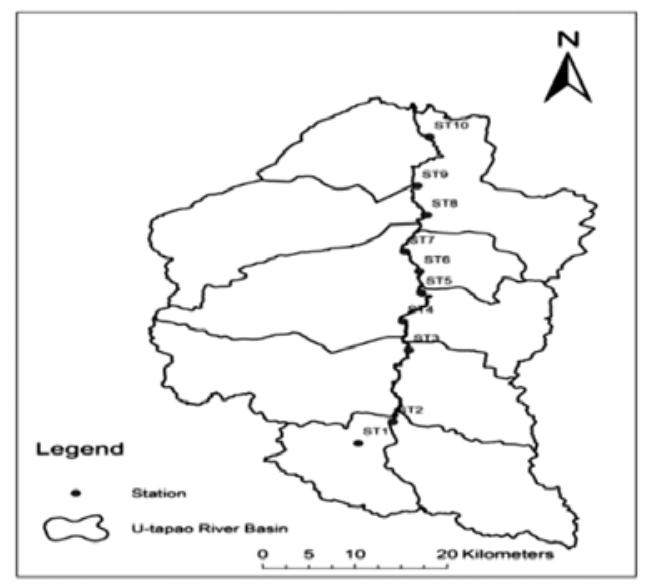

Fig. 2. Watersheds and corresponding monitoring stations of U-tapao River Basin

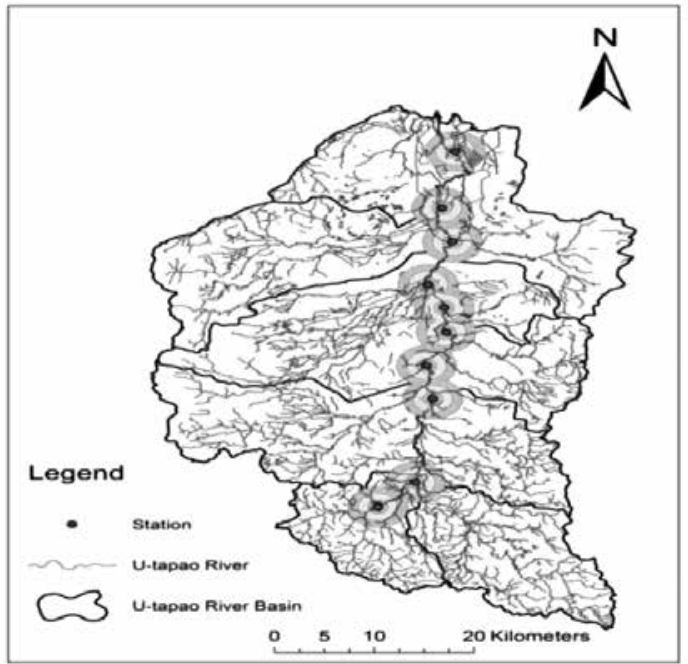

Fig. 3. $1000 \mathrm{~m}, 500 \mathrm{~m}$, and $200 \mathrm{~m}$ buffer zone in 10 monitoring stations in URB

\section{MATERIALS AND METHODS}

\section{Study Area}

The study was conducted on U-tapao river basin, a subbasin of Songkhla lake basin which is located at southern part of Thailand. The basin is about $60 \mathrm{~km}$ long from north to south, and $40 \mathrm{~km}$ wide from west to east, and total coverage is about $2,305 \mathrm{~km}^{2}$. The longitude and latitude of basin is $100^{\circ} 10^{\prime}$ through $100^{\circ} 37^{\prime} \mathrm{E}$ and $6^{\circ} 28^{\prime}$ through $7^{\circ} 10^{\prime} \mathrm{N}$ respectively (Fig.1). The dominating land use of the basin is agriculture especially rubber plantation. The land use change in this area was mainly caused by urban sprawl. The area consists of 10 watersheds, defined by Southern Remote Sensing, Thailand. All the sub-watersheds are mutually exclusive, and their sizes range from 104 to $348 \mathrm{~km}^{2}$. U-tapaoriver is one of the most important rivers of Songkhla Lake Basin which originates from Bantad Mountain and flows through Hatyai municipality before emptying into the outer part of Songkhla Lake, during its course of $90 \mathrm{kms}$, it receives a pollution load from both point and non-point sources (Gyawali et al. 2012).

Water Quality- Due to limitation of data, only water quality data from the year 2000-2009 were collected from existing monitoring framework done by the Regional Environment Office 16, Songkhla. Water quality monitoring stations were located at 10 sites throughout the U-tapao river basin (Fig. 1).The water quality parameters for this study were temperature (TEMP), $\mathrm{pH}$, biological oxygen demand (BOD), dissolved oxygen (DO), electrical conductivity (EC), suspended solid (SS), dissolved solid (DS), fecal coliform bacteria (FCB), ammonia $\left(\mathrm{NH}_{3}\right)$ and total phosphorous (TP). 
Land use- Area of land uses of the basin and percentages (2000-2009) were derived from the land use map, provided by the land use department, Thailand by using ArcGIS software. The original land use data set with 37 land use types were aggregated into four broad categories, (1) Forest land: evergreen forest, mangrove, swamp forest, planted forest etc.; (2) Agriculture land: rubber, orchid, paddy field etc (3) Urban: residential, industrial, institutional etc. (4) Water body: lake, river, reservoir, wetland, grass land, mining etc.

Spatial scales- The whole basin was divided into 10 watersheds and all the sub-watersheds are mutually exclusive, and their sizes range from 104.78 to 349.90 $\mathrm{km}^{2}$. ArcView GIS software was used to determine the composition of the land use and its characteristics within the 10 sub-watersheds. For each monitoring stations, ArcView's buffer facility was used to extract landscape data for the area $1000 \mathrm{~m}, 500 \mathrm{~m}$ and $200 \mathrm{~m}$ buffer that will allow a comparison of the influence of land use data on water quality parameters.

Statistical analysis- The impact of land use changes on water quality was assessed by analyzing both spatial and temporal relationships between land use and water quality parameters (WQP). In this study, the spatial relationship refers to how WQP varies with land use changes over space, while the temporal relationship refers to how WQP evolves with land use change over time. Descriptive statistics was used to explain general characteristics of land use and WQP. One way ANOVA was used to explain the spatial and temporal variations of land use indicators and WQP. To draw information about the relationship of land use and water quality and compare these relationships on different spatial scales, Karl Pearson's correlation analysis was used to determine whether land use factors have positive or negative influence on different water quality variables. To compare the influence on different scales, a simple linear bivariate regression was used. For each combination of variables, coefficients of determination $\left(\mathrm{R}^{2}\right)$ and significance levels (p) were compared to determine the relative importance of land use variables affecting water quality and the relative significance of different scales in terms of the impact on water quality. When $\mathrm{R}^{2}$ and $\mathrm{p}$ were same for the combination of the same variables at different scales, the regression slopes $\left(\beta_{1}\right)$ were further compared, with higher slopes indicating higher levels of impact.

\section{RESULTS}

\section{Land use distribution of URB}

U-tapao river basin has experienced land use change over last decade. Agriculture land use was the dominant land cover type in the basin about 80 percent in 2000 to about 74 percent in 2009 (Fig. 4). Analyzing the land use from year 2001 to 2009, agriculture land use was decreased about 7 percent whereas the forest land use was increased slightly $(0.34 \%)$. Urban and water body land uses were increased by about 4 percent, and 3 percent. Mostly agriculture land use was converted to urban land use due to socio-economic reason and it was drastically changed after the year of 2006. From correlation analysis, agriculture land use showed significant negative correlation with forest, urban, and water body $(\mathrm{r}=-0.74$, $-0.97 \&-0.96, \mathrm{p}<0.05)$ and urban land use showed significant positive correlation with forest $(\mathrm{r}=0.72, \mathrm{p}<$ 0.05 ). These results suggest that agricultural land is decreasing and converting to other land uses.

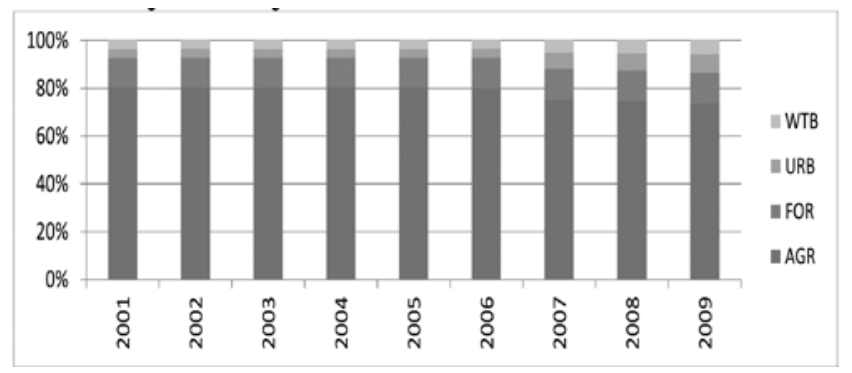

Fig. 4. Land use distribution of U-tapao river basin in percentage from year 2001 to 2009 in full-basin scale

\section{Spatial and Temporal variations of land use}

Analyzing the variance, by using one-way ANOVA technique, for temporal variation of land use pattern, agriculture, urban, and water body showed the significance variation $(F=14.45, p<0.05 ; F=9.26, p<0.05$; $\& \mathrm{~F}=6.43, \mathrm{p}<0.05)$ where forest land use did not show significant variation. For the case of spatial variation of agriculture land use, there was significance difference on mean values of agriculture land in spatial level $(\mathrm{F}=93.00$, $\mathrm{p}<0.05$ ). From post-hoc analysis, the highest significance mean percentage difference of agriculture land use was observed between watershed V and watershed VIII (24.29\%) (Fig 5). For the case of forest land use, there was significant difference between mean values in spatial level $(\mathrm{F}=379.97, \mathrm{p}<0.05)$ and the highest significant mean difference was observed between watershed II and watershed VIII (-24.59\%). For the case of urban land use, there was significant difference between mean values in spatial level $(\mathrm{F}=36.91, \mathrm{p}<0.05)$ and the highest significant mean difference was observed between watershed I and watershed IX $(-24.59 \%)$. For the case of water body, there was significant difference between mean values in spatial level $(\mathrm{F}=28.87, \mathrm{p}<0.05)$ and the highest significant mean difference was observed between watershed II and watershed IX (-12.47\%). 


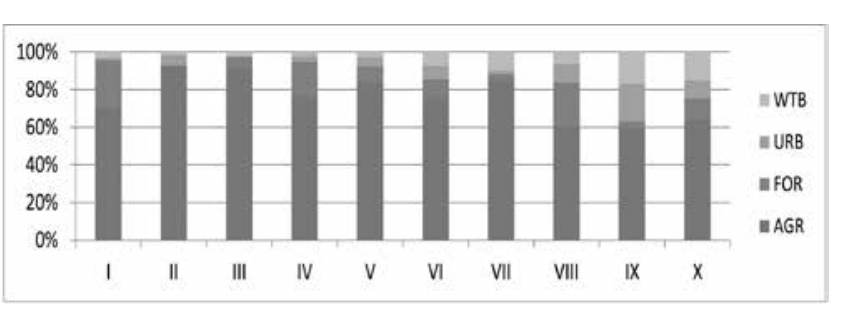

Fig. 5. Spatial variation of land use on 10 watersheds Spatial and Temporal variations of water quality-

There was significance difference on mean values of TEMP on both spatial and temporal level $(\mathrm{F}=11.936$, $\mathrm{p}<0.05 \& \mathrm{~F}=3.453, \mathrm{p}<0.05)$. There were significance difference on mean values of $\mathrm{pH}, \mathrm{EC}, \mathrm{DO}, \mathrm{BOD}$, and FCB on spatial level but not on temporal level $(\mathrm{F}=3.29$, $5.80,3.47,4.13,20.67, \mathrm{p}<0.05)$. There were significance difference on mean values of TP and $\mathrm{NH}_{3}$ on temporal level but not on spatial level $(10.78,3.30, \mathrm{p}<0.05)$. There was no significance difference on mean values of SS and DS on both spatial and temporal level.

\section{Correlation between land use and water}

The different types of land use showed correlation with some water quality variables in different scales. Agriculture land use showed significant negative correlation with TEMP in sub-watershed scale $(\mathrm{r}=-0.58$, $\mathrm{p}<0.05)$ and $1000 \mathrm{~m}$ buffer zone scale $(\mathrm{r}=-0.52, \mathrm{p}<0.05)$, with DS in sub-watershed scale $(\mathrm{r}=-0.71, \mathrm{p}<0.05)$ and full-basin scale $(r=-0.0 .61)$. Agriculture land use showed significant positive correlation with DO in sub-watershed scale $(r=0.37, p<0.05)$ and FCB in full basin scale $(r=$ $0.72, p<0.05)$ and negative correlation with BOD in subwatershed scale $(\mathrm{r}=-0.42, \mathrm{p}<0.05)$ and $\mathrm{SS}$ in $1000 \mathrm{~m}$ buffer zone scale $(r=-0.49, \mathrm{p}<0.05)$. In contrast to other studies, agriculture land use did not show as a major source of degrading water quality in any level of scales (Basnyatet al. 1999). Similarly, in full-basin scale, urban land use had significant positive correlation with DS $(r=0.60$, $\mathrm{p}<0.05)$ and FCB $(r=0.75, \mathrm{p}<0.05)$. In sub-watershed scale, urban land use had significant positive correlation with TEMP $(r=0.49, p<0.05), \operatorname{BOD}(r=0.24, p<0.05)$, and DS $(r=0.40, p<0.05)$ and negative correlation with DO $(\mathrm{r}=-0.24, \mathrm{p}<0.05)$. In $1000 \mathrm{~m}$ buffer zone scale, urban land use had significant positive correlation with TEMP $(\mathrm{r}=0.46, \mathrm{p}<0.05)$. However, urban land use showed the degrading water quality in all scales.

In full-basin scale, forest land use had significant positive correlation with $\mathrm{SS}(\mathrm{r}=0.58, \mathrm{p}<0.05)$, and $\mathrm{DO}$ $(\mathrm{r}=0.66, \mathrm{p}<0.05)$. In sub-watershed scale, forest land had significant negative correlation with $\mathrm{FCB}(\mathrm{r}=0.20$, $\mathrm{p}<0.05)$ and DS $(\mathrm{r}=0.36, \mathrm{p}<0.05)$. Even though, forest did not decrease SS, increment of DO with increment of forest land is improvement sign of water quality.
For the case of water body, in full-basin scale, it had significant positive correlation with $\mathrm{DO}(\mathrm{r}=0.58, \mathrm{p}<0.05)$ and negative correlation with FCB $(\mathrm{r}=-0.73, \mathrm{p}<0.05)$. In sub-watershed scale, water body had significant positive correlation with TEMP $(\mathrm{r}=0.42, \mathrm{p}<0.05)$, BOD $(\mathrm{r}=0.34$, $\mathrm{p}<0.05)$ and $\mathrm{DS}(\mathrm{r}=0.34, \mathrm{p}<0.05)$ and negative correlation with DO $(\mathrm{r}=-0.41, \mathrm{p}<0.05)$. In $1000 \mathrm{~m}$ and $500 \mathrm{~m}$ buffer zone, water body had significant positive correlation with $\mathrm{EC}(\mathrm{r}=0.56, \mathrm{p}<0.05)$.

Comparing relationship land use and water quality in different scales- Comparing the strength of relationship of water quality parameters with land use indicators by using bivariate regression model, we used $\mathrm{R}^{2}, \mathrm{p}$ value and $\beta_{1}$. For the case TEMP, there was no significance relationship between land use in full-basin scale, but in sub-watershed scale, TEMP had significance relationship with agriculture land, urban land and water body. In $1000 \mathrm{~m}$ buffer zone, TEMP had significant relationship with agriculture land and urban. For $500 \mathrm{~m}$ and $200 \mathrm{~m}$ buffer zones TEMP had significant relationship with agriculture. Comparing all these scales, TEMP showed higher level of relationship with land use indicators in sub-watershed scale. For the case of DO, it had significant relationship with forest and water body in full-basin scale. And, DO had significant relationship with agriculture, urban, and water body in sub-watershed scale. But, there was no significant relationship of TEMP with any types of land use in buffer zone scales $(1000 \mathrm{~m}$, $500 \mathrm{~m}$, and $200 \mathrm{~m})$. Linking forest land use and water body with DO, the full-basin scale approach is more appropriate. For the case of BOD, there was no significant relationship with land use indicators in full-basin scale and $1000 \mathrm{~m}, 500 \mathrm{~m}$, and $200 \mathrm{~m}$ buffer zone scales. In sub watershed scale, BOD had significant relationship with agriculture, urban and water body. Linking land use indicators with BOD, sub-watershed approach is more appropriate than other approaches. For the case of DS, it had significant relationship with agriculture land, forest land, and urban land in full-basin scale. Similarly, DS had significant relationship with agriculture land, forest land, urban land and water body in sub-watershed approach. But, there was no relationship between any types of land use with water quality in $1000 \mathrm{~m}, 500 \mathrm{~m}$ and $200 \mathrm{~m}$ buffer zone scales. Comparing different scales to link DS with land use indicators, forest and urban land uses can be better explained in full-basin scale whereas agriculture and water body can be better explained in sub-watershed scale. So, both scales can be used for this case.

For the case of SS, it had significant relationship with forest land in full-basin scale and agriculture land and urban land in $1000 \mathrm{~m}$ buffer zone. SS had significant relationship with agriculture land and urban land in 
$500 \mathrm{~m}$ buffer zone scale; similarly it had significant relationship with agriculture land and urban land in 500 $\mathrm{m}$ buffer zone. However, there was no relationship of SS with land uses in sub-watershed approach, so, for SS it is better to link with full-basin or $1000 \mathrm{~m}$ or $500 \mathrm{~m}$ buffer zone approaches. For the case of EC, it had significant relationship with water body in $1000 \mathrm{~m}$ buffer zone and $500 \mathrm{~m}$ buffer zone. There was no significant relationship of EC with full basin, sub-watershed and $200 \mathrm{~m}$ buffer zone scale. For the case of FCB, it had significant relationship with agriculture land, urban, and water body in fullbasin scale. In sub-watershed scale, FCB had significant relationship with forest land. There was no significant relationship between FCB with any types of land use in $1000 \mathrm{~m}, 500 \mathrm{~m}$ and $200 \mathrm{~m}$ buffer zone approaches. To sum up, linking FCB with agriculture, urban and water body full-basin is appropriate whereas linking with forest, subwatershed approach is appropriate.

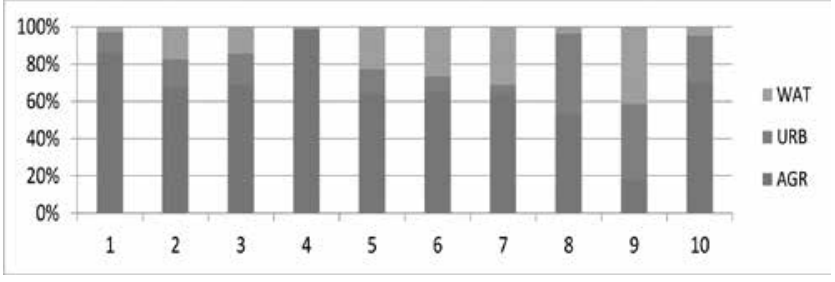

Fig. 6. Land use distribution of 10 monitoring stations in $1000 \mathrm{~m}$ buffer zone scale

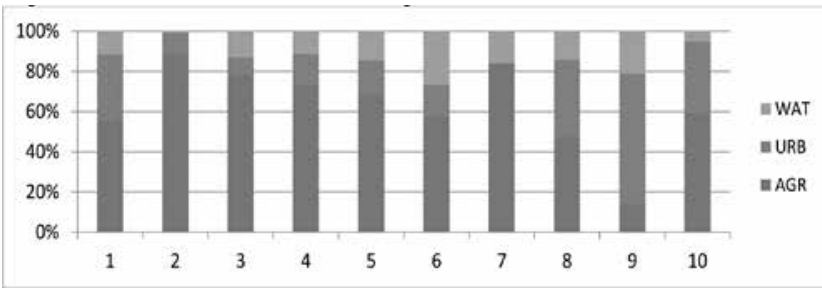

Fig. 7. Land use distribution of 10 monitoring stations in $500 \mathrm{~m}$ buffer zone scale

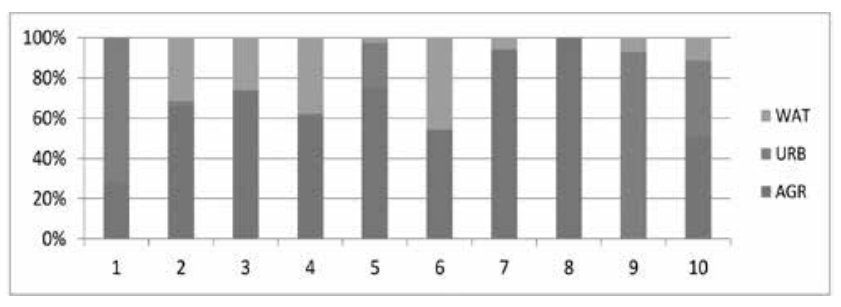

Fig. 8. Land use distribution of $\mathbf{1 0}$ monitoring stations in 200m buffer zone scale

\section{DISCUSSION}

Land use/land coverchangeis one the major environmental changes happening around the globe and consequently it has been affecting water quality of river. For example, the land uses of U-tapao river basin has been changing rapidly, especially from agriculture land to urban land from year 2006 to 2009 due to rapid population growth, urbanization, industrialization in the basin (Gyawali et al. 2012). The analysis of urban development during the 2000-2009 period indicated that most of the urban growth occurred in the portion of basin where agriculture lands were available for new development. During this period, urban land increased more than two fold (approximately $84.206 \mathrm{~km}^{2}$ to $180.589 \mathrm{~km}^{2}$ and $7.83 \%$ of the total basin area) (Gyawali et al. 2012). Since, urban land showed positive correlation with DS, FCB and TEMP and negative correlation with DO. It showed the increment of urban land create pressure on water quality. Due to unsystematic urbanization, surface water pollution in U-tapao river is extremely high and it is due to uncontrolled and unregulated effluents and waste water from residential and industrial areas (Gyawali et al. 2012)

. The results of the study strongly highlight the negative impact of urbanization on river system and the water quality has been highly influenced by the pollution from point sources as well as non-point sources from urban areas. Generally, forest is mostly related to good water quality and especially forest land in riparian zone of river plays a vital role in reducing the amount of pollutants, but in U-tapao river, there is no forest in the riparian zone which might be one of causes of pollution of river. Surprisingly, agriculture was not acted as degraded water quality, as suggested by other studies (Tong \& Chen 2002, Li et al. 2009, Ahearn et al. 2005). Agriculture was negatively associated with TEMP, BOD, DS and SS and positively associated with DO. The watersheds with a lower percent agricultural land will have much higher percentage in developed area that might become the primary pollution sources to the river water (Azyana \& NikNorulaini 2012). Since, agriculture land use had negative correlation with urban land and build locations are nearly surrounded with agriculture, so urban land is likely to take over agriculture land. This is evidence that urbanization is a major factor that has led to the decrease of agriculture and which might be one of the causes of decreasing water quality of U-tapaoriver (Huang et al. 2011).

In this study, TEMP had significant relationship with changing land uses of agriculture, urban and water body in sub-watershed scale but it did not show any significant relationship with land uses in full-basin scale. DOhad significant relationship with changing land uses of forest and water body in full-basin scale and agriculture, urban and water body in sub-watershed scale. BOD had significant relationship with changing land uses of agriculture, urban and water body in sub-watershed scale and it did not show any significant relationship with other scales. DS had significant relationship with changing 
land uses of agriculture, forest, and urban in full-basin scale and agriculture, forest, urban, and water body in sub-watershed scale and it did not show any significant relationship with changing land uses in all buffer zone scales. SS had significant relationship with forest in fullbasin scale and agriculture and urban in $1000 \mathrm{~m}, 500 \mathrm{~m}$, and $200 \mathrm{~m}$ buffer zone scales. For the case of FCB, it showed significant relationship with changing land uses with agriculture, urban and water body in full-basin scale and forest with sub-watershed scale. EC showed significant relationship with changing land use of water body in $1000 \mathrm{~m}$ and $500 \mathrm{~m}$ buffer zone scales. Since, the knowledge of appropriate water quality parameters and spatial scales is very important on linking land uses with water quality. In this study, only water quality parameters like TEMP, EC, DO, BOD, DS, SS, and FCB should be chosen for linking land use and it depends on spatial scale

For scale analysis, a relationship between land use and water quality parameters found in one level scale might not be same or even opposite in other scales. For this reason, spatial scale analysis is an important factor for linking land use and water quality. For example, agriculture land use had significant negative correlation with DS and positive correlation with FCB in full-basin scale. Similarly, it had significant negative correlation with TEMP, BOD and DS and significant positive correlation with sub-watershed scale. And, it had only significant negative correlation with TEMP and SS in $1000 \mathrm{~m}, 500 \mathrm{~m}$, and $200 \mathrm{~m}$ buffer zone scales. Since, four water quality parameters can be linked with agriculture land use in sub- watershed scale, it is better to use subwatershed scale for linking agriculture land use with water quality parameters. For the case of urban land, it had significant positive correlation with DS and FCB in full-basin scale. It had significant positive correlation with DS, BOD, and TEMP and significant negative correlation with DO in sub-watershed scale. It had significant positive correlation with SS in $1000 \mathrm{~m}, 500 \mathrm{~m}$, and $200 \mathrm{~m}$ buffer zone scales. The results suggest that, using sub-watershed approach to link urban land use to water quality parameters is the best approach. This relationship may explain the influence of point sources as well as non-point sources pollution that is commonly associated with urbanized areas (Sliva \& Williams, 2001). After agriculture and urban land uses, the forest land use that appeared important in determining water quality and land use. For the case of forest, it had significant negative correlation with DS and significant positive correlation with DO and SS in full-basin scale and it had significant negative correlation with DS and significant positive correlation with FCB in watershed scale. There is no forest land in riparian zone of river, so, the relationship of forest and water quality parameters in buffer zone scales does not exist. Since, forest land use is distributed outer part of basin, it is better to link water quality with forest in full-basin scale rather than sub-watershed scale. For the case of water body, it had significant negative correlation with DO and FCB in full-basin scale. And, it had significant positive correlation with TEMP, BOD, and DS and significant negative correlation with DO in sub-watershed scale. It had only positive correlation with EC with $1000 \mathrm{~m}$ and $500 \mathrm{~m}$ buffer zone scales. Comparing all scales, it is better to link water quality with water body in sub-watershed scale.

Several researchers have addressed the issue of whether land use near river is a better predictor of water quality than land use over the entire watershed (Sliva \& Williams 2001). Our analysis results show water quality to be correlated with sub-watershed scale slightly better than with buffer zone and full basin approach even though forest land use was better explained in full-basin scale. And, these days, sub-watershed scale approach has been commonly used for land-water studies (Huang et al. 2011). So, for river basin management aspect, it is better to link water quality with land uses in sub-watershed approach and it can be furthered extended other water quality parameters as well as hydrology and metrological parameters.

\section{CONCLUSION}

In this study, the water quality parameters like TEMP, DO, BOD, SS, DS, FCB and EC are appropriate parameters to link with land use indicators since they showed significant relationship agriculture, forest, urban, and water body in different scales. For the case of land uses, agriculture and urban are important land use indicators to link water quality variables. For the case of scale analysis, subwatershed approach is the best to link land use and water quality parameters for effective river basin management. By understanding of appropriate water quality variables and important land use indicators helps to link land use and water quality parameters for decision making process in river basin management. This study also demonstrates the importance of considering the geographical scale on linking land use with water quality parameters. The understanding of the linkage between land-use and river water quality with scale is critical to the management of healthy ecosystem of the basin. Such understanding may help future planning and efforts to alleviate water quality problems of the river basin. 


\section{REFERENCES}

Ahearn, D.S., Sheibley, R.S., Dahlgren, R.A., Anderson, M., Jonson, J., Tate, K.W. 2005. Land use and land cover influence on water quality in the last free-flowing river draining the western Sierra Nevada, California. Journal of Hydrology 313: 234-247.

Azyana, Y., NikNorulaini, N.A. 2012. The Entire Catchment and Site Buffer Radii Landscape Variables, Urban Land Use as Predictors of Water Quality Variation. International Journal of Environmental Science and Development 3(2): 141-145.

Basnyat, P., Teeter, L.D., Flynn, K.M., Lockaby, B.G. 1999. Relationships between Landscape Characteristics and Nonpoint Source Pollution Inputs to Coastal Estuaries. Environmental Management 23(4): 539-549.

Gyawali, S., Techato, K., Monprupussorn, S. 2012. The influence of urbanization on water quality of U-tapao river, Thailand, Proc $2^{\text {nd }}$ Int. Conf. on Green and Sustainable Innovation, Chiang Mai, Thailand, 2012.

Gyawali, S., Techato, K. and Yuangyai,C. 2012. Effects of Industrial Waste Disposal on the Surface Water Quality of U-tapao River, Thailand. ProcIntConf on Environment Science and Engineering, Bangkok, Thailand, 2012.

Huang, J. Li, Q., Pontius, R.G., Klemas, V., Hong, H. 2011. Detecting the Dynamic Linkage between Landscape Characteristics and Water Quality in a Subtropical Coastal Watershed, Southeast China. Environmental Management.

Huang, J., Li, Q., Pontius, R.G., Klemas, V., Hong, H. 2011. Detecting the Dynamic Linkage between Landscape Characteristics and Water Quality in a Subtropical Coastal Watershed, Southeast China. Environmental Management 2011.

Hunsaker, C.T., Levine, D.A. 1995. Hierarchical approaches to the study of water quality in rivers. BioScience 45: 193-202.

Jarvie, H.P., Oguchi, T., Neal, C. 2002. Exploring the Linkages Between River Water Chemistry and Watershed Characteristics Using GIS-Based Catchment and Locality Analyses. Regional Environmental Change 3(1\&3): 36-50.
Johnson, L.B., Richards, C., Host, G.E., Arthur, J.W. 1997. Landscape influences on water chemistry on Mid-western stream ecosystems. Freshwat. Biol 37: 193-208.

Li, S., Gu, S., Tan, X., Zhang, Q. 2009. Water quality in the upper Han River basin, China: The impacts of land use/land cover in riparian buffer zone. Journal of Hazardous Materials 165:317-324.

Ngoye, E., Machiwa, J.F. 2004. The Influence of LandUse Patterns in the Ruvu River Watershed on Water Quality in the River System. Physics and Chemistry of the Earth 29(15\&18): 11611166.

Ojutiku, R.O., Kolo, J. 2011. Temporal and spatial variation of physcio-chemical parameters of river Chanchaga, Niger State. Nigeria, Journal of Applied Biosciences 47: 3242-3255.

Pratt, B., Chang, H. 2012. Effects of land cover, topography, and built structure on seasonal water quality at multiple spatial scales. Journal of Hazardous Materials.

Sliva, L., Williams, D.D. 2001. Buffer zone versus whole catchment approaches to studying land use impact on river water quality. Water Research 35(14): 3462-3472.

Tong, S.T.Y., Chen, W. 2002. Modeling the Relationship between Land Use and Surface Water Quality. Journal of Environmental Management 66(4): 377-393.

Tu, J. and Xia, Z. G. 2006. Assessing the impact of land use changes on water quality across multiple spatial scales in eastern Massachusetts. Middle States Geographer 39: 34-42.

Zampella, R.A., Procopio, N.A., Lathrop, R.G., Dow, C.L. 2007. Relationship of land-useland-cover patterns and surface-water quality in the Mullica river basin. Journal of the American Water Resources Association 43(3): 594-604. 